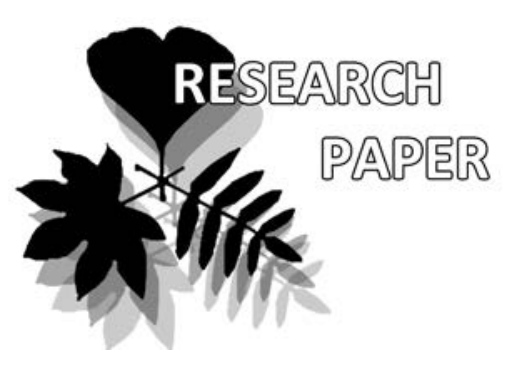

\title{
In vitro potato plantlet development under different polychromatic LED spectra and dynamic illumination
}

\author{
Olga V. Nakonechnaya ${ }^{1 *}$, Evgeniy P. Subbotin ${ }^{2}$, \\ Olga V. Grishchenko ${ }^{1}$, Irina V. Gafitskaya ${ }^{1}$, Irina Yu. Orlovskaya ${ }^{1}$, \\ Alexander S. Kholin', Dariya O. Goltsova ${ }^{2}$, Natalia I. Subbotina ${ }^{2}$, \\ Victor P. Bulgakov ${ }^{1}$, Yuri N. Kulchin ${ }^{2}$
}

\author{
Olga V. Nakonechnaya ${ }^{1 *}$ \\ e-mail:markelova@biosoil.ru \\ Evgeniy P. Subbotin ${ }^{2}$ \\ e-mail: s.e.p@list.ru \\ Olga V. Grishchenko ${ }^{1}$ \\ e-mail: grishchenkoov@gmail.com \\ Irina V. Gafitskaya ${ }^{1}$ \\ e-mail: gafitskaya@biosoil.ru \\ Irina Yu. Orlovskava \\ e-mail: irina-orlovskay@mail.ru \\ Alexander S. Kholin ${ }^{2}$ \\ e-mail: a_kholin@ iacp.dvo.ru \\ Dariya O. Goltsova ${ }^{2}$ \\ e-mail: gd89@list.ru \\ Natalia I. Subbotina ${ }^{2}$ \\ e-mail: sale789@mail.ru \\ Victor P. Bulgakov ${ }^{1}$ \\ e-mail: bulgakov@biosoil.ru \\ Yuri N. Kulchin ${ }^{2}$ \\ e-mail: kulchin@iacp.dvo.ru
}

${ }^{1}$ Federal Scientific Center of the East Asia Terrestrial Biodiversity FEB RAS,

Vladivostok, Russia

${ }^{2}$ Institute of Automation and Control

Processes FEB RAS, Vladivostok, Russia

\section{* corresponding author}

Manuscript received: 22.09 .2020

Review completed: 04.12.2020

Accepted for publication: 08.12.2020

Published online: 11.12.2020

\begin{abstract}
A B S T R A C T
We studied growth of potato plantlets of two cultivars under different constant polychromatic light-emitting diodes (LEDs) and dynamic lighting with the spectrum modifications during growth. Light sources constructed by us were sunbox $\mathrm{SB}$, red-green-blue RGB, and full spectrum FS, red-blue. White luminescent lamps were used as control light. Dynamic lighting was achieved by transferring groups of plantlets from one box to another. Red/green/blue portions in the light sources were (in percents): 39R/39 G/22B for SB, 63R/21G/16B for RGB, 74R/8G/18B for FS, and $22 \mathrm{R} / 49 \mathrm{G} / 29 \mathrm{~B}$ for control. PPFD was set at $45 \mu \mathrm{mol} / \mathrm{m}^{2} \mathrm{~s}$. Morphometric measurements were made 14 and 28 days after planting. Plantlets developed differently from initial stages. Cultivar 'Red Scarlett' appeared to be more susceptible to different lighting than 'Innovator'. Light variations RGB and RGB-SB were the most favorable for plantlet development. This is the first report on the dynamic lighting application for growing potato plantlets.
\end{abstract}

Keywords: Solanum tuberosum, artificial light, different spectra, light emitting diodes, in vitro, micropropagation, cultivar, cultivation

\section{P E 3 Ю M E}

Наконечная О.В., Субботин Е.П., Грищенко О.В., Гафицкая И.В., Орловская И.Ю., Хомин А.С., Гольцова А.О., Субботина Н.И., Булгаков В.П., Кумьчин Ю.Н. Развитие микрорастений картофемя in vitro поА разАичными полихромными СА спектрами и Аинамическим освещением. Мы исследовали развитие микрорастений картофеля Авух сортов поА разАичными постоянными полихромными светоАИодными $(\mathrm{C} A)$ спектрами и Аинамическим освещением с изменением спектра в процессе роста. Нами были сконструированы следующие источники освещения: солнечный бокс SB, красно-зелено-синий RGB, и полный спектр FS, красно-синий. В качестве контрольного света использовались белые мюминесцентные мампы. Аинамическое освещение достигалось путем переноса группы микрорастений из оАного бокса в Аругой. Аоля красного/зеленого/синего спектров в источниках света была (в процентах): 39R/39G/22B Аля SB, 63R/21G/16B Аля RGB, 74R/8G/18B мля FS и 22R/49G/29B Аля контроля. PPFD был установлен на уровне 45 мкмоль $/ \mathrm{m}^{2}$ с. Морфометрические измерения проводили через 14 и 28 дней от начала эксперимента. Микрорастения развивались по-разному с самых начальных стаАий эксперимента. Сорт 'Red Scarlett' оказался более восприимчивым к изменению освещения, чем 'Innovator'. Варианты освещения RGB и RGB-SB оказались наиболее благоприятными Аля развития микрорастеий картофеля. Это первое сообщение о применении динамического освещения А^я выращивания микрорастений картофеля.

КАючевые слова: Solanum tuberosum, картофель, искусственный свет, разные спектры, светодиоды, микроклональное размножение, in vitro, сорт, выращивание
The development of technologies of all year-round cultivation of agricultural crops in protected conditions using artificial illumination meets the challenges in the field of food security. These technologies allow reducing risks associated with farming in open field and receive stable harvest independently from the season. Potato, Solanum tuberosum L., is one of the most important crops cultivated all over the world. The use of seed material of a high quality can determine the abundance of harvest. The maximum yield can be achieved by using elite and super elite tubers, produced via method of apical meristems. The method helps to clean the seed material from viruses, and sanitated material can be easily multiplied using microclonal propagation method in vitro. The method helps to rapidly propagate valuable and rare plant cultivars (Anisimov \& Chugunov 2014).

Light is the one of critical factors affecting plant growth and developing. Growth, morphogenesis, and tuberization of potato in vitro are affected by light. By changing (modifying) light parameters (spectrum, intensity, photoperiod) researchers can control plant development in vitro (Seabrook 2005), and thus avoid the usage of plant growth regulators that may cause atypical conditions (Aksenova et 
al. 1989, Seabrook \& Douglass 1998 and others). The creation of optimal artificial lighting conditions for obtaining a high-quality crop for different potato cultivars is important. Today's state of the development of controlled light-emitting diode (LED) technology provides great potential for studying the processes of plant morphogenesis and creating conditions for improving growth, productivity and increasing plant resistance.

Extensive experimental data have been accumulated on the influence of different types of light on the development of the potato plantlets (Seabrook 2005 and articles herein). However, to the best of our knowledge, no experiments with dynamic lighting and modified spectra during plant cultivation have been conducted. Nevertheless, such approach may be a helpful tool in improving growth of potato plantlets. Therefore, the aim of our work was to study the effect of different polychromatic LED light sources and dynamic illumination with spectra modified during the experiment on growth of two potato cultivars 'Red Scarlett' and 'Innovator'.

\section{MATERIAL AND METHODS Plant material and culture conditions}

We used two cultivars (cv.) of the Solanum tuberosum L. plantlets, 'Red Scarlett' and 'Innovator', in our experiments. Red Scarlet is an early cultivar, resistant to many diseases, with good storage performance. It is characterized with an intensive and rapid accumulation of tuber yield with good quality. Its harvest levels depend a lot from the soil, climate, and weather conditions, and agrotechnics. 'Innovator' is a medium-early cultivar with good characteristics, high level of resistance to the main diseases, and high yield potential. The cultivar is unpretentious to soil, resistant to unstable weather, cold and heat.

Sterile microplants were cultivated on Murashige \& Skoog (1962) solid medium, supplemented with kinetin $(2 \mathrm{mg} / \mathrm{L})$ and indoleacetic acid $(1 \mathrm{mg} / \mathrm{L})$, in test-tubes at $24 \pm 1{ }^{\circ} \mathrm{C}$ under light with luminescent lamps OSRAM L 36W/765 (Russia/Poland) for 14 days. For the experiment, we cut the grown plantlets into equal single-node fragments with leaves of the same size, and placed them on the same medium in a culture chamber at $24 \pm 1^{\circ} \mathrm{C}$ under different light treatments. The cuttings grew for 28 days with a $16 \mathrm{~h}$ day/ $8 \mathrm{~h}$ night illumination.

\section{Lighting conditions and the set up of the experiment}

Light sources were constructed in the Institute of automation and control processes FEB RAS. We used three different matrix LED light

Table 1. Spectral properties of the matrix lightemitting diode light sources.

\begin{tabular}{lcccc}
\hline $\begin{array}{l}\text { Spectral } \\
\text { wavelength } \\
\text { range, nm }\end{array}$ & $\begin{array}{c}\text { Control } \\
\text { luminescent }\end{array}$ & SB & RGB & FS \\
\cline { 2 - 5 } Blue 400-500 & 29 & 22 & 16 & 18 \\
Green 500-600 & 49 & 39 & 21 & 8 \\
Red 600-700 & 22 & 39 & 63 & 14 \\
\hline
\end{tabular}

sources with distinct spectra for the experiment: sunbox SB, a newly constructed polychromatic spectrum approaching to a solar spectrum in a wavelength range 400-700 nm (Nakonechnaya et al. 2019); full spectrum FS, with mainly red and blue wavelength range, often used in greenhouses; and red-green-blue RGB, containing red, green and blue diodes. We used luminescent lamps as a control. Light intensity for all light sources was equal to $45 \mu \mathrm{mol} / \mathrm{m}^{2} \mathrm{~s}$ (measured with the spectrophotometer TKA-Spectrum («TKA», Russia). Spectral characteristics of all light sources are shown in Fig. 1 and Table 1.

We cultivated plantlets under four light treatments for two weeks. After that, plantlets in each box were randomly divided into 3 equal groups. We left one group at the same box for further growth, and transferred two other groups into other boxes with LED lighting, in order to organize a dynamic lighting via changing the spectrum during plantlets development. Plantlets grew in the modified lighting conditions for the next two weeks. Control plantlets grew under luminescent light during all cultivation period. Thus, we obtained 9 variants of illumination: SB, RGB, FS, SB-RGB, SB-FS, RGB-SB, RGB-FS, FS-SB, FS-RGB. 28 days after planting, we measured plantlet height, fresh and dry mass of shoots and roots, internodes length, and length and width of leaves. We also measured plantlet height, leaves and roots number after two weeks of culturing, before transferring plantlets to other boxes. We repeated the experiment for three times with 15 plantlets in each of ten treatments. Fresh weight was measured using electronic balance (Vibra AJH-220CE, Shinko Denshi Co, LTD, Japan).

\section{Statistical analysis}

We processed the data using Microsoft Office Excel and Statistica, version 13.3 (StatSoft Inc., USA). The results are represented as the means \pm standard errors of means. Analysis of variances (one-way ANOVA) using Fisher's protected least significant difference (PLSD) post-hoc test was applied. A difference of $\mathrm{P}<0.05$ was considered significant.

\section{RES U LT S}

Morphometric characteristics of the potato plantlets after two weeks of culturing (before the change of the spectra) are shown in Fig. 2. Our data displayed plantlets sensitivity to light composition from the early growth periods, and

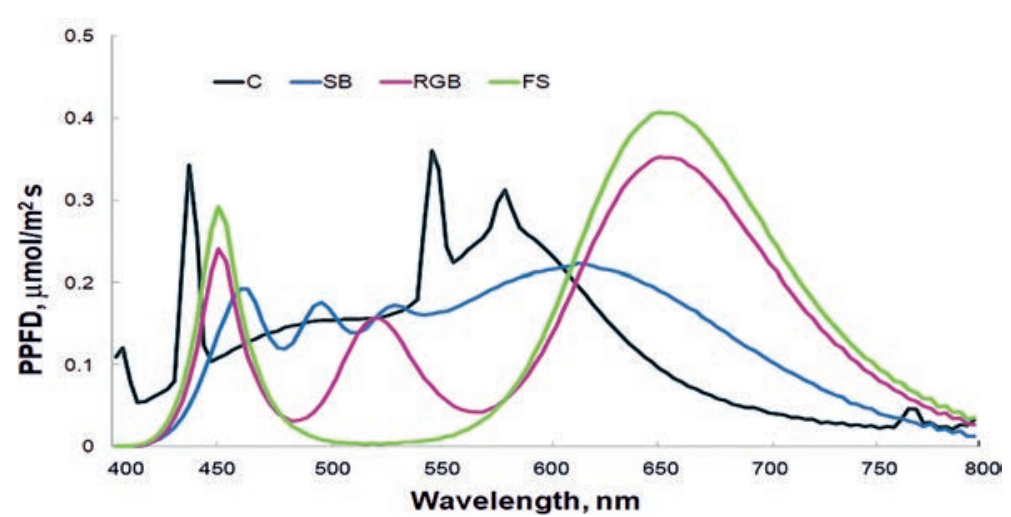

Figure 1 Spectral characteristics of the LED and luminescent light sources used in the experiment 
responses were cultivar-specific. For some parameters, 'Red Scarlett' plantlets responded more intensively than 'Innovator' plantlets. Thus, maximal height for 'Red Scarlett' plantlets was noted for control and RGB-RGB plantlets (48 and $45 \mathrm{~mm}$, respectively). SB-SB provided growth of mediumsize plantlets $(41 \mathrm{~mm})$, and FS-FS caused the formation of the shortest plantlets $(38 \mathrm{~mm}$ ) (Fig. 2a). SB-SB light provided a decrease in leaves number (4.2), comparing with control plantlets (4.9), and number of roots in all plantlets under LED lights was equal to that in control plantlets (5.3; 5.7; 6.9; and 5.9, respectively). Whereas 'Innovator' plantlets showed no reliable difference in plantlets growth $(68,66,65$, and $68 \mathrm{~mm}$ ) as well as in number of roots $(5.3 ; 6 ; 6.2$; and 5.9). At the same time, number of leaves in plantlets under LED light treatments was significantly lower than that in control plantlets (4.3; 4.4; 4.6; and 5.4, respectively) (Fig. 2).

Analysis of the potato plantlets measurements after four weeks of growth under modified spectra showed that plantlets of different cultivars responded in a similar way. We made this conclusion based on the trend lines in Fig. 3. For the cv. 'Red Scarlett' the highest plantlets developed under RGB-RGB (67 mm). They were significantly higher than plantlets of other experimental groups, except control $(62 \mathrm{~mm})$. The shortest plantlets developed under SB-FS and FS-FS lights (49 and $50 \mathrm{~mm}$, respectively). Plantlets of other light treatments did not significantly differ from each other (Fig. 3).

The highest plantlets of the cv. 'Innovator' were observed under the control light. Plantlets under RGB-RGB, RGBFS, and FS-SB did not significantly differ from control, but were higher than plantlets under SB-SB, SB-RGB, SB-FS, RGB-FS, and FS-RGB. We noted maximal lengths of internodes in 'Red Scarlett' plantlets. For cv. 'Innovator', it was difficult to identify a spectrum that would clearly affect the elongation or shortening of the plantlets. We observed the highest values of leaf length and width for cv. 'Red Scarlett' plantlets under FS-RGB, and for cv. 'Innovator' plantlets under FS-RGB (data not shown).

Fresh shoot mass accumulation was the highest in plantlets cv. 'Red Scarlett' grown under RGB-RGB, SB-RGB, and FS-RGB (274, 274, and $267 \mathrm{mg}$, respectively) (Fig. 4a). Plantlets under SB-SB and SB-FS showed a reliable decrease in this parameter, in comparison with RGB-RGB plantlets (222, and $234 \mathrm{mg}$, respectively). Control plantlets did not differ in fresh shoot mass accumulation from plantlets of other light treatments.

For cv. 'Innovator' plantlets, we observed maximal fresh shoot mass accumulation under FS-SB, control, and SB-FS lights $(250,245$, and $241 \mathrm{mg}$, respectively). However, no significant difference was found among plantlets of all experimental groups except FS, where plantlets accumulated the minimal fresh shoot mass (212 mg) (Fig. 4a).

We received similar tendency when analyzed dry shoot mass accumulation. Plantlets of most of the experimental groups did not reliably differ from each other in this characteristic, except SB (21 mg) for cv. 'Red Scarlett' with lower dry shoot biomass values than in RGB and SB-RGB (24 mg) plantlets. For cv. 'Innovator', FS plantlets $(20 \mathrm{mg})$ accumulated significantly less biomass than SB-FS, RGB-SB, and FS-SB plantlets $(24,24$, and $25 \mathrm{mg}$, respectively) (Fig. 4b).

We noticed a significant decrease in the levels of fresh root biomass accumulation in 'Red Scarlett' plantlets grown under C, SB-RGB, RGB-FS, and FS-RGB light treatments $(142,141,149$, and $148 \mathrm{mg}$, respectively), in comparison with RGB-SB plantlets (178 mg) (Fig. 5a). Levels of dry
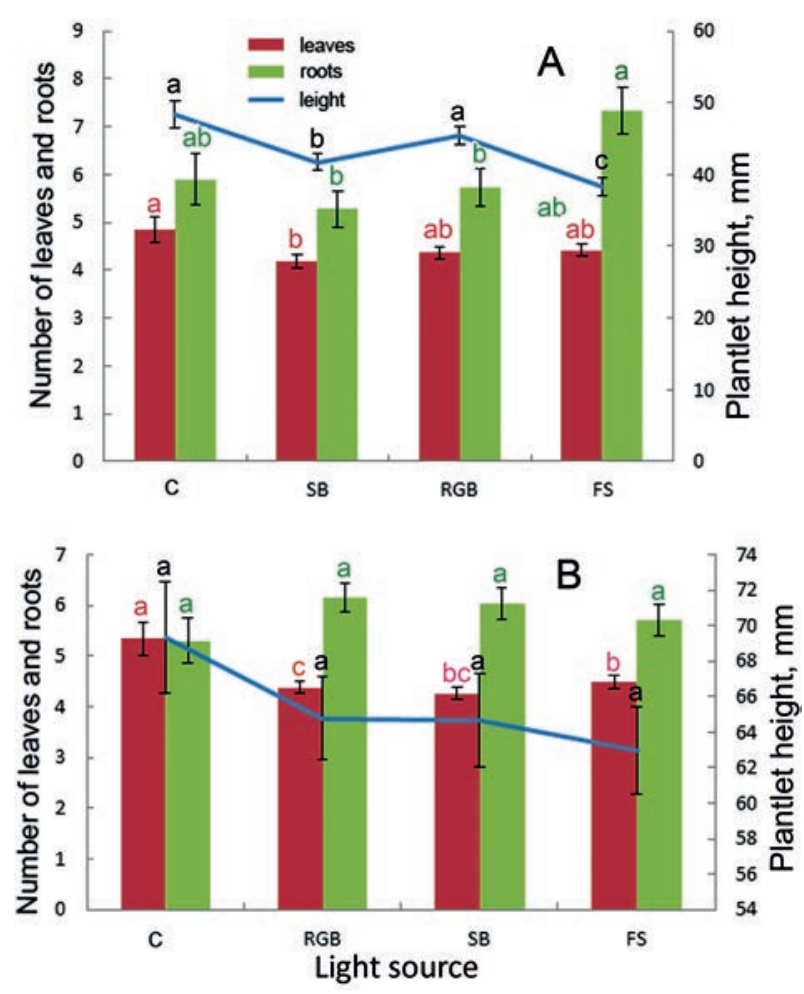

Figure 2 Morphometric characteristics of potato plantlets cv. 'Red Scarlett' (A) and 'Innovator' (B) after two weeks of culturing under different light treatments. $\mathrm{C}-$ control (luminescent light). LED lights: SB - sunbox, RGB - red-green-blue, FS - full spectrum (red-blue). Different letters above the columns indicate statistically significant differences of means ( $(\mathrm{P}<0.05)$, Fisher's LSD 

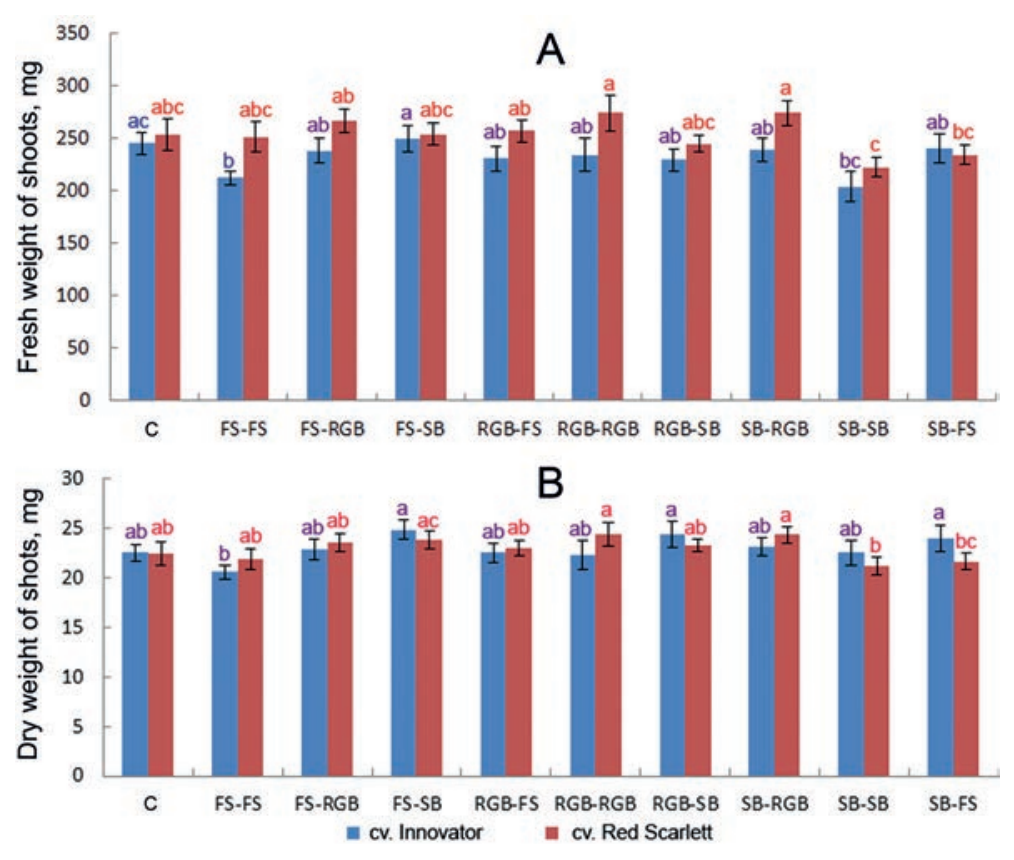

Figure 4 Fresh (A) and dry (B) biomass of shoots of the potato plantlets cvs. 'Red Scarlett' and 'Innovator' after four weeks of culturing under modified LED light spectra. C - control (luminescent light). LED lights: SB - sunbox, RGB red-green-blue, FS - full spectrum (red-blue). Different letters above the columns indicate statistically significant differences of means $(\mathrm{P}<0.05)$, Fisher's LSD
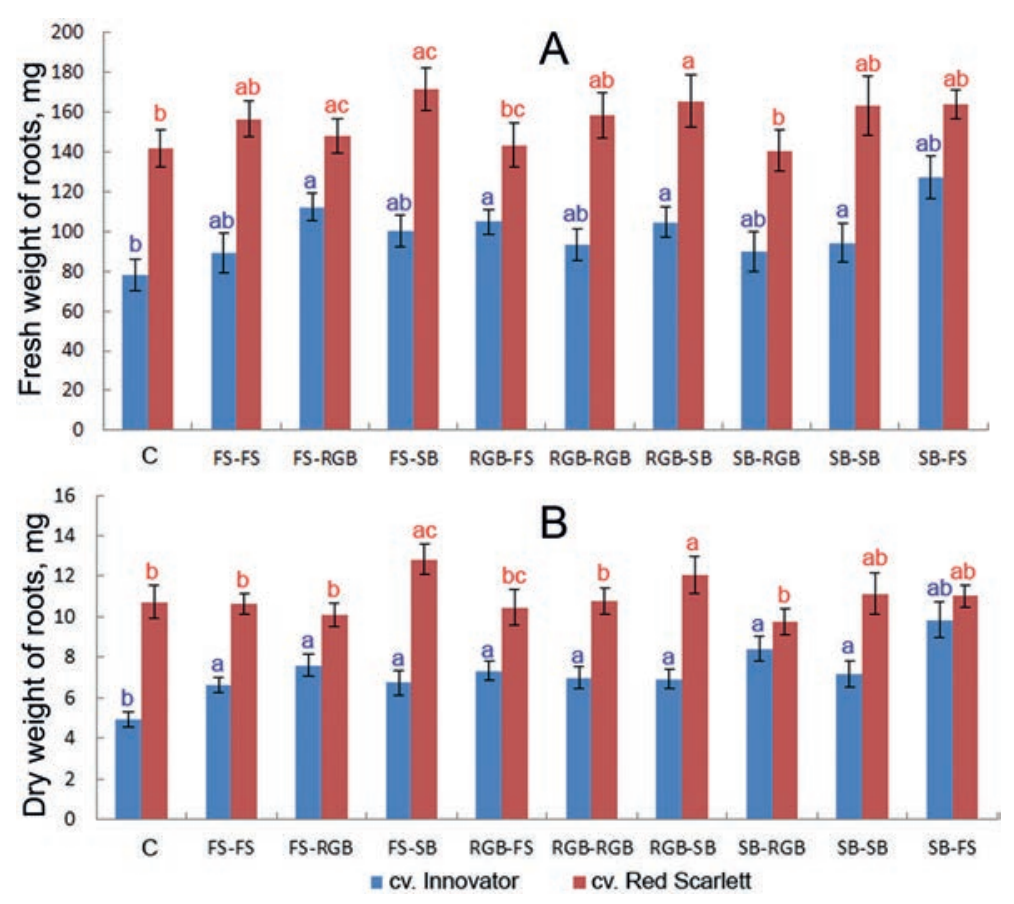

Figure 5 Fresh (A) and dry (B) mass of roots of potato plantlets cvs. 'Red Scarlett' and 'Innovator' after four weeks of culturing under modified LED spectra. C control luminescent light, SB - sunbox, RGB - red-green-blue light, FS - full spectrum (red-blue)

root biomass accumulation were also reliably higher in RGB-SB, and FS-SB plantlets (13 and $12.8 \mathrm{mg}$ ), comparing with control, RGB-RGB, FS-FS, SB-RGB, and FS-RGB plantlets $(10.7,10.8,10.6,9.7$, and $10 \mathrm{mg}$, respectively).

For cv. 'Innovator' plantlets, we found a reliable decrease in fresh root biomass accumulation by control plantlets
(78 mg), comparing with SB-SB, RGB-SB, RGB-FS, and FS-RGB plantlets (103, 105, 105, and $112 \mathrm{mg}$ ). Dry root mass accumulation levels were also lower in control plantlets $(5 \mathrm{mg})$, comparing with plantlets of other experimental groups except SB-FS (6 mg) (Fig. 5b).

It is interesting to note that roots mass/total plant mass ratio was higher in 'Red Scarlett' plantlets than in 'Innovator' plantlets (Fig. 6). In general, we can note a common tendency of the root system development in plantlets of two cvs. depending on the light spectrum.

\section{DISCUSSIO N}

Based on the results, we can suppose that rapid development of plantlets of both cvs. under control light during the first two weeks was due to a high portion of green light in the spectrum (Tabe 1). Responses to green light are typically low-light responses suggesting that they may contribute to the adaptation to growth under foliage of within close proximity to other plants (Wang \& Folta 2013). Ma et al. (2015) showed that addition of green light to a mixture of red and blue LEDs significantly increased stem height, stem diameter, leaf area, and vegetative growth of potato plantlets in vitro, comparing with red-blue spectrum. At the same time, the minimal height of plantlets of both cvs. under FS can be caused with the least portion of green in FS.

We observed the highest plantlets of the 'Red Scarlett' cv. under RGB-RGB at the end of the experiment. Moreover, the transfer of plantlets from SB to RGB caused a significant increase in plantlets growth. We did not detect reliable growth changes in other lighting groups. We assume that an increase in plantlets height is caused by a combination of blue, green and red portions in the spectra (Table 1).

Among plantlets of cv. 'Innovator', the shortest specimens grew under RGB-SB, and plantlets grown under SB were reliably smaller than plantlets under control light. The SB and FS spectra slowed down stem elongation, although the blue region in their spectra, often responsible for plant shortening, was quite small. One can assume that this behavior is connected with portions of green light more, than with blue spectrum levels. At the same time, 'Red Scarlett' plantlets, transferred under $\mathrm{SB}$, were characterized with higher levels of fresh shoot mass accumulation, comparing with other spectra, except RGB-RGB. We showed previously for arugula Eruca sativa cv. 'Dikovina', that under similar light conditions and dynamic light modifications, plants under FS-RGB and RGB-SB were among the group with the highest values of fresh shoot biomass accumulation (Nakonechnaya et al. 2021, in press). In the present study with potato plantlets, we noted similar positive impact of 


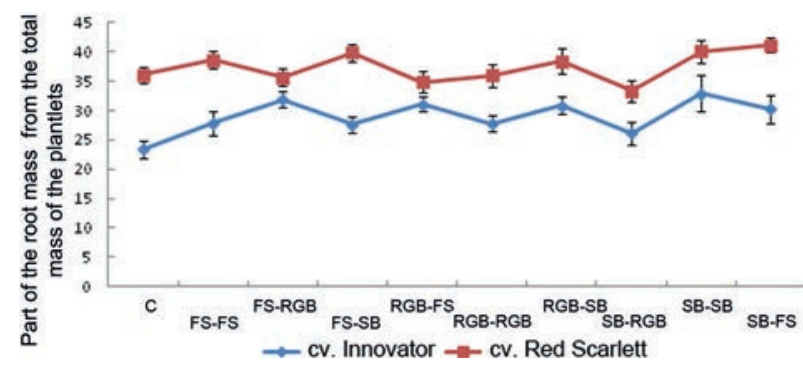

Figure 5 Ratio of mass of fresh roots to total biomass of potato plantlets cvs. 'Red Scarlett' and 'Innovator' after four weeks of culturing in conditions of dynamically modified light spectra. The data are performed as percents

RGB spectrum on shoot mass accumulation. We observed the dry mass increase in plantlets of the same experimental groups as with the fresh mass. This allowed us to conclude that the percentage of water accumulation was the same, meaning that mechanisms of water regulation were similar in all plantlets regardless of the light spectrum.

We detected the least shoot dry mass values in 'Red Scarlett' plantlets grown under SB-SB. The values differed significantly from those for RGB-RGB and SB-RGB. Dry mass accumulation increased when plantlets were transferred from SB to RGB light (Fig. 5) that let us to conclude that RGB light with less green part, in comparison with $\mathrm{SB}$ light, is more favorable for shoot mass accumulation. Although in should be noted that the root development tended to be decreased in SB-RGB plantlets, comparing with SB specimens.

We showed previously for arugula Eruca sativa cv. 'Dikovina' that a transfer of plants from other light treatments into SB led to a decrease in root development (Nakonechnaya et al. 2021, in press). In contrary, in the present study 'Red Scarlett' plantlets transferred to SB were characterized with increase in dry weight of roots, comparing with RGB-RGB and FS-FS plantlets that grew under constant light during the whole experiment. In case of 'Innovator' plantlets, we observed a tendency to a better root growth in plantlets transferred to $\mathrm{SB}$ in comparison to those grown under constant light though it was not supported statistically. It was shown previously for Lactuca sativa cv. 'Waldmann's Green' that increase in the green portion in the spectrum caused a decrease in fresh and dry biomass accumulation in plants (Kim et al. 2004). In our research, we did not see such a relationship.

Plantlets of different cultivars developed differently in our experiment. Despite higher stem lengths 'Innovator' plantlets accumulated less roots and shoots biomass, comparing with 'Red Scarlett' plantlets, which were slowly growing short but robust plantlets. These differences did not depend on the light treatment and were distinctive characteristics of each cultivar determined genetically. According to the results obtained, we conclude that RGB-RGB and RGB-SB light treatments were more favorable for optimal potato plantlets development for both cvs. SB light source can be recommended for growing potato plantlets on the second stage of culturing.

\section{CONCLUSION}

Our study showed that plantlets response to different light treatments was cultivar-specific, though plantlets responded similarly to some light alterations. Cv. 'Red Scarlett' was more susceptible to light modifications than 'Innovator'. The differences between plantlets of various experimental groups were evident at the initial period of experiments, during first two weeks of culturing. White luminescent lamps can successfully be replaced by LED light sources in culture chambers for cultivating and propagating potato plantlets in vitro. The use of dynamic lighting, that is the modification of the spectrum during the growth of potato plantlets, make it possible to change their characteristics in a promising direction.

\section{ACKNOWLEDGEMENTS}

This work was financially supported by the Ministry of Science and Higher Education of the Russian Federation (Agreement No. 075-15-2019-1696, from 02.12.2019. Unique project identifier - RFMEFI60419X0229).

\section{LITERATURE CITED}

Aksenova, N.P., T.N. Konstantinova \& T.N. Chaflakhyan 1989. Morphogenetic effects of blue and red light during exposure of overground and underground organs of potato in culture in vitro. Dolkady Akademii Nauk SSSR 305:508-512. [Аксенова Н.П., Константинова Т.Н., Чайлохян М.X. 1989. Морфогенетический эффект синего и красного света при освещении надземных и подземных органов картофеля в культуре in vitro / / Аоклады Академии наук. Т. 305, № 2. C. 508-512].

Anisimov, B.V. \& V.S. Chugunov 2014. Innovative scheme of original potato seed production. Kartofel' $i$ ovoshchi 6: 25-27 (in Russian). [Анисимов Б.В., Чугунов B.С. 2014. Инновационная схема оригинального семеноводства картофемя // Картофемь и овощи. № 6. С. 25-27].

Gafitskaya, I. V., O.V. Nakonechnaya, O.V. Grishchenko, V.P. Bulgakov, Y.N. Zhuravlev, E.P. Subbotin \& Y.N. Kulchin 2019. Growth of Solanum tuberosum plantlets in vitro under LED light sources. In: Asia-Pacific Conference on Fundamental Problems of Opto-and Microelectronics (Y.N. Kulchin, R.V. Romashko \& J.-C. Jiang, eds), 2017 11024:110240E. International Society for Optics and Photonics, Taipei.

Kim, H.H., G.D. Goins, R.M. Wheeler \& J.C. Sager 2004. Green-light supplementation for enhanced lettuce growth under red- and bluelight-emitting diodes. HortScience 39: 1617-1622.

Ma, X., Y. Wang, M. Liu, J. Xu \& Z. Xu 2015. Effects of green and red lights on the growth and morphogenesis of potato (Solanum tuberosum L.) plantlets in vitro. Scientific Horticulture 190:104-109.

Murashige, T. \& F. Skoog 1962. A revised medium for rapid growth and bio-assays with tobacco tissue cultures. Physiologia Plantarum 15(3):473-497.

Nakonechnaya, O.V., I.V. Gafitskaya, E.V. Burkovskaya, Y.A. Khrolenko, O.V. Grishchenko, Y.N. Zhuravlev, E.P. Subbotin \& Y.N. Kulchin 2019. Effect of light intensity on the morphogenesis of Stevia rebaudiana under in vitro conditions. Russian Journal of Plant Physiology 66(4):656-663.

Nakonechnaya, O.V., O.V. Grishchenko, Y.A. Khrolenko, V.P. Bulgakov, E.V. Burkovskaya, V.P. Grigorchuk, N.A. Prokuda, A.S. Kholin, I.V. Gafitskaya, A.V. Micheeva, I.Yu. Orlovskaya, M.L. Burdukovskii, E.P. Subbotin \& 
Y.N. Kulchin 2021. Influence of LED lighting on morphogenesis, content of ascorbic acid, P, K, CA in Eruca sativa plants. Russian Journal of Plant Physiology 68(2): in press.

Seabrook, J.E. 2005. Light effects on the growth and morphogenesis of potato (Solanum tuberosum) in vitro: a review. American journal of potato research 82(5):353-367.

Seabrook, J.E.A. \& L.K. Douglass 1998. Prevention of stem growth inhibition and alleviation of intumescence formation in potato planflets in vitro by yellow filters. American Journal of Potato Research 75:219-224.

Wang, Y. \& K. Folta 2013. Contributions of green light to plant growth and development. American Journal of Botany 100(1):70-78. 